\title{
The dietary, productivity, and economic value of swiftlet (Aerodramus fuciphagus) farming in East Kalimantan, Indonesia
}

\author{
MURSIDAH $^{1,2, \bullet}$, ABUBAKAR M. LAHJIE ${ }^{3}$, MASJAYA ${ }^{4}$, YAYA RAYADIN ${ }^{3}$, YOSEP RUSLIM $^{3, \bullet \bullet}$, \\ MEIDI B. JUDINNUR ${ }^{3}$, ANDY $^{3}$ \\ ${ }^{1}$ Faculty of Agriculture, Universitas Mulawarman. J1. Pasir Balengkong, Kampus Gunung Kelua, Samarinda 75123, East Kalimantan, Indonesia. \\ Tel.: +62-541-749159, 749314, Fax.: +62-541-738741, `email: mursidah.spmm@gmail.com; \\ ${ }^{2}$ Graduate Program in Forestry, Universitas Mulawarman. Jl. Ki Hajar Dewantara, Gunung Kelua, Samarinda 75123, East Kalimantan, Indonesia \\ ${ }^{3}$ Faculty of Forestry, Universitas Mulawarman. Jl. Penajam, Kampus Gunung Kelua, Samarinda 75123, East Kalimantan, Indonesia. \\ Tel.: +62-541-735089, Fax.: +62-541-735379, • email: yruslim@gmail.com \\ ${ }^{4}$ Faculty of Social and Political Science, Universitas Mulawarman. J1. Muara Muntai, Kampus Gunung Kelua, Samarinda 75123, East Kalimantan, \\ Indonesia
}

Manuscript received: 17 April 2021. Revision accepted: 31 May 2021

\begin{abstract}
Mursidah, Lahjie AM, Masjaya, Rayadin Y, Ruslim Y, Judinnur MB, Andy. 2021. The dietary, productivity, and economic value of swiftlet (Aerodramus fuciphagus) farming in East Kalimantan, Indonesia. Biodiversitas 22: 2528-2537. Edible-nest swiftlets have many health benefits. The availability of edible-nest swiftlets from caves is decreasing, while the demand for edible-nest swiftlets is getting higher. Swiftlet farming is carried out to meet this demand. The location of swiftlet farming should be close to the feeding sources. Swiftlet is flying insectivorous animals. A financial feasibility assessment is carried out to determine the feasibility of the business. This study aims to determine the composition of land cover, determine the insect order of feed sources, and analyze the production and financial feasibility of swiftlet farming. The study was carried out from June to December 2019. The composition of land cover was determined using the supervised classification method, the order of insects was known using the insect determination key, while production and financial feasibility were analyzed using the Net B/C, NPV, IRR, and PP methods. The observed location and swiftlet farming were determined purposefully. The results of this study show that the land cover was dominated by shrubs $(56.58 \%)$ and secondary forest (27.3\%); both types of land cover are suitable for swiftlet farming locations. The dominant insects found in shrubs and wetland shrubs are Diptera (78.25\%), in rice fields are Diptera (86.7\%) and in oil palm plantations are Diptera (29.4\%) and Hymenoptera (27.78\%). Edible-nest swiftlets harvest begins in the third year, with a production period of between 17-34 years. From the financial feasibility, it can be concluded that swiftlet farming is feasible.
\end{abstract}

Keywords: Financial feasibility, insect, land cover, non-timber forest products, swiftlet farming

\section{INTRODUCTION}

Forest biodiversity has the potential to produce wood products (timber forest product or TFP) and non-timber products (non-timber forest products or NTFPs). The forest management system also determines the sustainability of forest existence, including the TFP and NTFP that it produces. Tropical forest experiences a lot of exploitation, TFP for the supply of industrial raw materials and NTFPs utilized by people who depend on forests (Rist et al. 2012; Delgado et al. 2016: Mursidah et al. 2020). In fact, if the results are not overexploited, forests will at least be useful as a source of livelihood for forest dwellers and as conservation of forests (Sisak et al. 2016; Harbi et al 2018). Biodiversity of NTFPs is derived from flora and fauna found in a forest. Unfortunately, overexploitation and neglection of sustainability create some NTFP availability is increasingly rare in nature (Sarmah 2012). Edible-nest swiftlets are non-timber forest products derived from fauna, i.e., swiftlet.

Edible-nest swiftlets is an edible birds nest (EBN), which contains protein, amino acids, and minerals (Jamaluddin et al. 2019; Zulkifli et al. 2019). Edible-nest swiftlets are beneficial to improve the human immune system and slow the aging process (Ma and Liu 2012; Wong 2013; Chan et al. 2015; Hou et al. 2015; Zhang et al. 2015; Chua and Zukefli 2016; Careena et al. 2018; Babji and Daud 2019; Daud et al. 2019). Meanwhile, under normal consumption of EBN glycoproteins, the undigested compounds of EBN glycopeptides can carry a prebiotic effect in the intestinal environment. If viewed from a health perspective, EBN is useful as an antiviral, antioxidant, and neuroprotective. In addition, EBN helps treat cardiometabolic disease and bone degeneration (Chye et al. 2017).

Edible-nest swiftlets can be used as a functional food to encourage the advancement of the edible-nest swiftlets industry (Ramji and Rahman 2013; Chua and Zukefli 2016; Nor et al. 2016; Hou et al. 2015; Shukri et al. 2018; Daud et al. 2019) and make the nest swiftlet as one of the world's largest food industry (Babji et al. 2015). Potential health benefits of edible-nest swiftlets result in increased world demand for edible-nest swiftlets, especially from China and Hong Kong. The high demand for edible-nest swiftlets (Manchi and Sankaran 2014) has driven the rapid growth of swiftlet farming in Southeast Asia, where there are 
abundant food sources and a suitable climate for swiftlet (Vimala et al. 2012; Hoang et al. 2014; Cadigal 2015; Hoang et al. 2015; Thorburn 2015; Chua and Zukefli 2016; Connolly 2016; Fischer and Kaaden 2016).

Until now, Indonesia has become a major producer and exporter of edible-nest swiftlets in the world. Exports of Indonesia's edible-nest swiftlets for the five-year period (2015-2019) had a positive trend of $34.94 \%$. Indonesia's edible-nest swiftlets export in the January-September 2019 period was valued at US\$205.71 million. Based on the trade map in 2019, Indonesia's edible-nest swiftlets export contributed to $48.16 \%$ of the total world edible-nest swiftlets export. In the same period, in 2020, edible-nest swiftlets export increased by $34.45 \%$ or US\$276.58. The main export destination of the Indonesian edible-nest swiftlets is China, with a value of US\$ 219.08 million, or $60.19 \%$ of all Indonesian edible-nest swiftlets exports (Ashari 2020).

A habitat that provides an abundant source of feed is a preferred location for swiftlet for foraging areas and is one of the considerations of a swiftlet farmer to establish a swiftlet house in that location (Nugroho and Budiman 2013). Swiftlets are insectivores, consuming flying insects that are dominated by the Hymenoptera and Diptera orders (Lourie and Tompkins 2000; Fujita and Leh 2020). The insects commonly found in their bolus are the orders of Diptera, Hymenoptera, Coleoptera, and Odonata. The dominant order of forage insects that feed swiftlet are Hymenoptera (89.8\%) (bees, wasps, flying ants), Coleoptera (8.3\%) (beetles, ladybugs, fireflies), Homoptera $(1.7 \%)$ (whiteflies, fleas, leafhoppers), and Diptera $(0.2 \%)$ (mosquitoes, flies). Meanwhile, when viewed at the family level, the Formicidae family is the type of feed insect mostly consumed by swiftlets, reaching $98.2 \%$ of the Hymenoptera order or $88.2 \%$ of the total swiftlet feed (Lourie and Tompkins 2000; Nituda and Nuneza 2016; Ahmad et al. 2019).

Each area of the swiftlet farming has its own uniqueness, either geographically, the population of these birds' food sources and microenvironment, including whether the area swiftlet farming is man-made or natural habitat (Ibrahim et al. 2011; Saengkrajang et al. 2013; Looi and Omar in 2016; Zulkifli et al. 2019). One of the islands that produce edible-nest swiftlets is Borneo (Looi and Omar 2016). In East Kalimantan, Kota Bangun Subdistrict, which is located in Kutai Kartanegara District, is one of the areas of swiftlet farming development (Mursidah et al. 2020). Referring to aforementioned background, this study was conducted to determine the composition of land cover, examine the order of insect, production, and financial feasibility of swiftlet farming in Kota Bangun Sub-district, Indonesia.

\section{MATERIALS AND METHODS}

\section{Study area}

This study was conducted in Kota Bangun Subdistrict, Kutai Kartanegara District, East Kalimantan,
Indonesia. The study site is located at coordinates $0^{\circ} 07^{\prime}-$ $0^{\circ} 36$ 'S and $116^{\circ} 27^{\prime}-116^{\circ} 46^{\prime}$ ' E. There were 3 swiftlet houses studied, 2 in the Village of Kedang Murung and 1 in the village of Sebelimbingan (Figure 1).

\section{Procedures \\ Data collection}

The research was begun in June 2019 and ended six months later, in December 2019. It is dry season between June and mid-October, while late October to December is the rainy season. The research was initiated with an orientation, secondary data collection through library research, and then continued with primary data collection using direct observation in the field and interviews with swiftlet farmers.

The guided qualification method (maximum likelihood) was used to determine the type of land cover. To observe the types of insects found in the observed land cover, a plot of 1 ha was taken which is considered representative, then an observation subplot of $10 \mathrm{~m} \times 10 \mathrm{~m}$ was made at 10 points on the plot which were considered representative. Observations were made from $06.00 \mathrm{am}$ to $05.00 \mathrm{pm}$. The insects were caught in 2 ways, using yellow sticky traps and a D-vac suction. Identification of insect orders using the Insect Determination Key. The determination of the swiftlet farmer as a respondent used a purposive sampling technique (Sugiyono 2016), with consideration of the scale of the business, based on the area of the swiftlet house to be observed. The respondents were selected for being swiftlet farmers with productive swiftlet houses of different sizes $\left(192 \mathrm{~m}^{2}, 256 \mathrm{~m}^{2}\right.$, and $\left.800 \mathrm{~m}^{2}\right)$. To find out the production, costs, revenue, income, and feasibility of swiftlet farming, observation and in-depth interviews with selected respondents (swiftlet farmers) were conducted.

\section{Model of the business scale}

The business scale is distinguished by the swiftlet house area. There are three swiftlet houses observed, with different areas, namely $192 \mathrm{~m}^{2}, 256 \mathrm{~m}^{2}$, and $800 \mathrm{~m}^{2}$. Determination of the business scale of swiftlet farming in this study was based on the size of the swiftlet house, which includes length, width, area, the height of each floor and the number of floors (Table 1).

The data on swiftlet farming and edible-nest swiftlet production of this study were presented descriptively and quantitatively (Mursidah et al. 2020).

Table 1. The business scale of swiftlet farming, including length, width, area, the height of each floor and the number of floors in the swiftlet house.

\begin{tabular}{cccccc}
\hline $\begin{array}{c}\text { Model of } \\
\text { the business } \\
\text { scale }\end{array}$ & $\begin{array}{c}\text { Length } \\
(\mathbf{m})\end{array}$ & $\begin{array}{c}\text { Width } \\
(\mathbf{m})\end{array}$ & $\begin{array}{c}\text { Area } \\
\left.\mathbf{( m}^{\mathbf{2}}\right)\end{array}$ & $\begin{array}{c}\text { Height } \\
\text { of each } \\
\text { floor }(\mathbf{m})\end{array}$ & $\begin{array}{c}\text { Number } \\
\text { of floors }\end{array}$ \\
\hline Model 1 & 8 & 6 & 192 & 2 & 4 \\
Model 2 & 8 & 8 & 256 & 2 & 4 \\
Model 3 & 20 & 8 & 800 & 2 & 5 \\
\hline
\end{tabular}




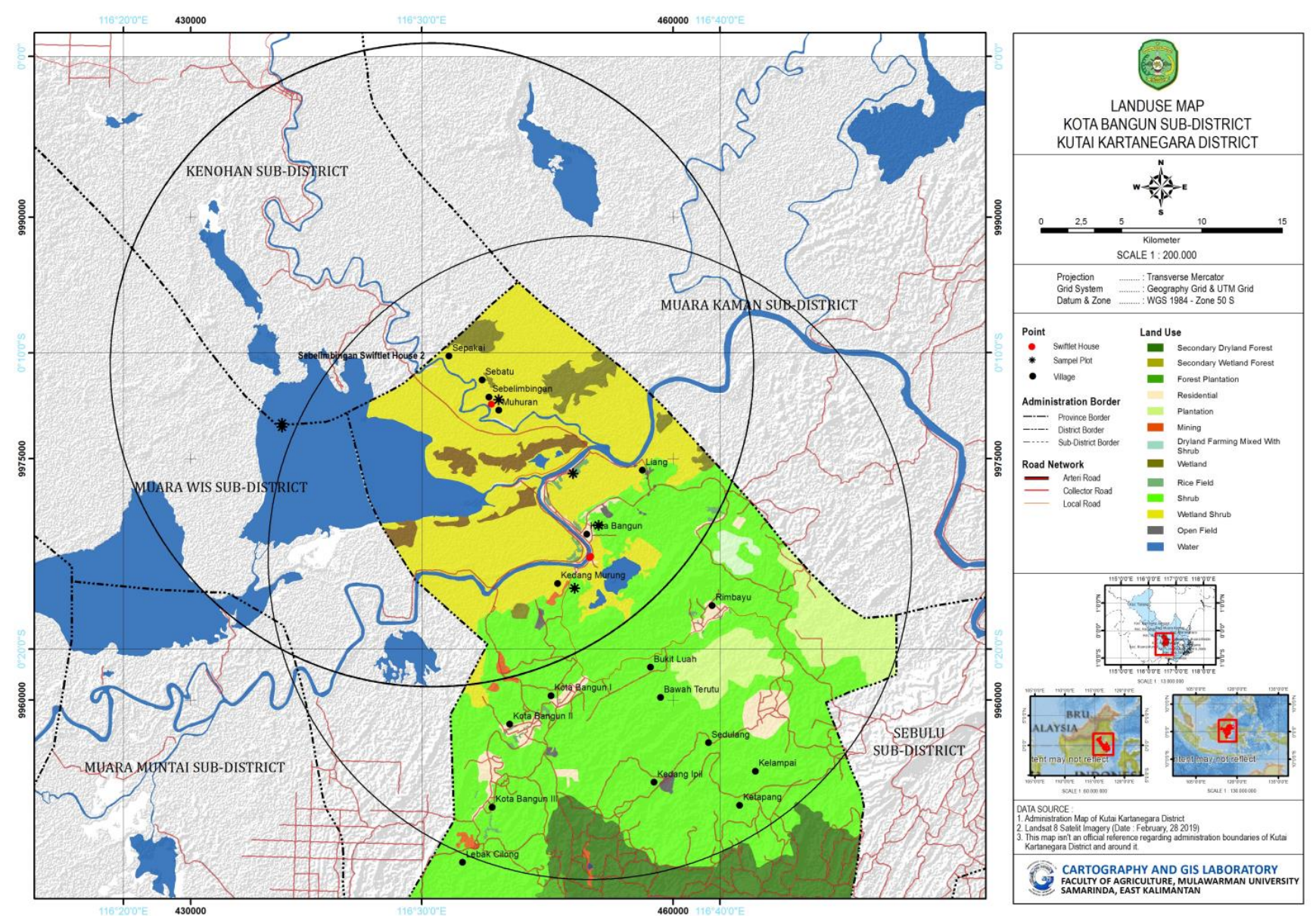

Figure 1. Observed swiftlet house's location, Kedang Murung and Sebelimbingan Village of Kota Bangun Sub-district, Kutai Kartanegara District, East Kalimantan, Indonesia $(\bullet)$ and land use map of the research is in Kota Bangun Sub-district

\section{Production evaluation and population}

Edible-nest swiftlet production was calculated per year during the economic life of the observed swiftlet house, and the average production per year (AP) and marginal production (MP) from year to year were calculated. AP was calculated by dividing production from year $\mathrm{t}$ to year $\mathrm{t}$, while MP was the difference in production from year to year (Mursidah et al. 2020, Rosyidi 2020).

$$
\mathrm{AP}=P t / t
$$

Where: AP: average product, Pt: production at age $t, t$ : age

$$
\mathrm{MP}=\frac{P_{t}-P_{t-1}}{t-t_{-1}}
$$

Where: MP: marginal product, Pt: production at age t, $\mathrm{P}_{\mathrm{t}-1}$ : previous production, $\mathrm{t}$ : age

The number of swiftlet in a swiftlet house can be estimated using the number of edible-nest swiftlets harvested in one breeding season, in which each nest consists of 2 productive birds. The number of non-breeding birds was estimated to be $3 \%$ of the population. The sum of the breeding and non-breeding pairs is the total population of swiftlet in the nest (Rahman et al. 2018). The equation used is:

Total pairs $=$ Breeding individuals + Non-breeding individuals

\section{Economic value}

The economic value of swiftlet farming is seen in its financial feasibility. The financial feasibility assessment was analyzed by considering the Net B/C (net benefit-cost ratio), NPV or net present value, IRR or internal rate of return, and PP or payback period (Arshad 2012; Duguma 2013; Banerjee 2015; Hopkinson 2016; Sososutikno and Gasperz 2017; $\mathrm{Ke}$ et al. 2018; Asciuto et al. 2019; Mursidah et al. 2020; Nigussie et al. 2020).

\section{Net B/C (Net benefit-cost ratio)}

The present value of the net positive benefits divided by the present value of the negative net benefits gives the net $\mathrm{B} / \mathrm{C}$.

$$
N e t B / C=\frac{\sum_{t=1}^{n} N B t(+)}{\sum_{t=1}^{n} N B t(-)}
$$

The project is feasible or profitable if Net $\mathrm{B} / \mathrm{C}>1$, not feasible if Net $\mathrm{B} / \mathrm{C}<1$, and the project is neither profitable nor losing capital if Net $\mathrm{B} / \mathrm{C}=0$. 


\section{NPV (Present Net Value)}

NPV is obtained by subtracting between the present value of the benefit and the present value of the cost.

$$
\mathrm{NPV}=\sum_{t=1}^{n} \frac{B t-C t}{(1+i)^{t}}
$$

Where: Bt: benefit of gross profit at year $\mathrm{t}, \mathrm{Ct}$ : cost at year $\mathrm{t}$, i: discount factor, $\mathrm{n}$ : economic age of the project

The project is feasible or profitable if NPV $>0$, not feasible if NPV $<0$, and the project is not getting profit if $\mathrm{NPV}=0$

\section{IRR (Internal Rate of Return)}

IRR is obtained if the discount rate for the project's $\mathrm{NPV}=0$, or if the discount rate for the benefit-cost ratio is $=1$.

$$
\operatorname{IRR}=i^{\prime}+\frac{N P V^{\prime}}{N P V^{\prime}+N P V^{\prime \prime}}\left(i^{\prime \prime}-i^{\prime}\right)
$$

Where: NPV': positive NPV, NPV': negative NPV, i': the interest rate when NPV is positive, i": the interest rate when NPV is negative.

The project is feasible or profitable if IRR > i, not feasible if IRR $<\mathrm{i}$, and if IRR $=\mathrm{i}$ is not getting profit.

\section{PP (Payback Period)}

The time required to return the total investment costs incurred for a project is called the payback period.

$$
\mathrm{PP}=n+\frac{(a-b)}{(c-b)} \times 1 \text { years }
$$

Where: n: the most recent year for which the cumulative cash flows were negative, a: the initial investment, $\mathrm{b}$ : the cumulative cash flows for $\mathrm{n}$ years, $\mathrm{c}$ : the accumulated amount of cash flow for $n+1$ year.

The project is feasible or profitable if $\mathrm{PP}<$ economic age of the project, but the project is not feasible if PP > economic age of the project, and the project is neither profitable nor taking a loss if PP is equal to the economic age of the project.

\section{RESULTS AND DISCUSSION}

\section{Land cover and insects}

The land cover found in Kota Bangun includes water bodies, shrubs, wetland shrubs, secondary wetland forest, secondary dryland forest, plantation forest, mixed dryland farming, plantations, settlements, wetlands, open land, mining, and rice fields (Figure 1).
Natural physical conditions (land cover) affect the diversity of naturally available feed (Begon et al. 2006). Table 2 shows that Kota Bangun Sub-district is an ideal location for swiftlet house locations; most $(96.92 \%)$ of its area $(107,958.27$ hectares) is a source of swiftlet feed. The dominant land cover is shrubs covering 41,395.99 ha $(38.34 \%)$, secondary dryland forest covering $27,932.87$ ha $(25.87 \%)$, and wetland shrubs covering 19,689.02 ha $(18.24 \%)$. Insects are animals that have a wide habitat distribution ranging from mountains, forests, agricultural fields, human settlements in urban areas (Taradipa et al. 2019).

Abundant feed and a short distance to the location of the feed is an ideal location for the swiftlet house. In the morning, before the swiftlet colony leaves the building, the swiftlet mothers first grab the insects, then immediately return to feed the young. The source of swiftlet feed can be originated from forests, oil palm plantation areas, livestock, wetlands, lakes, or rivers (Idris et al. 2014; Nugroho and Budiman 2013).

The availability of various insects in a place or land are associated with different foraging intensities. Swiftlet will choose a foraging habitat based on the quality of land cover, namely the land cover that provides the highest profit, in the form of the availability of flying insects as abundant feed (Sanchez-Clavijo et al. 2016; Ahmad et al. 2019).

In shrub and wetland shrub, which are the most dominant land cover in Kota Bangun District, insects originating from the Diptera order are mostly found $(78.25 \%)$. The dominant insects found in rice fields are Diptera $(86,7 \%)$ and Hemiptera $(7.14 \%)$, which are also the main food components of swiftlet (Lourie and Tompkins 2000; Razali et al. 2015). The highest foraging intensity of swiftlet is found in habitats of water bodies, forested areas, and open rice fields (Petkliang et al. 2017). The most intensive foraging occurs over water bodies, which indicates the greater abundance of both aquatic species above water and terrestrial insects on banks adjacent to water bodies.

Table 2. Land cover of Kota Bangun Sub-district, Kutai Kartanegara District, East Kalimantan, Indonesia in 2019

\begin{tabular}{lll}
\hline Land cover & Area (ha) & $\begin{array}{l}\text { Percentage } \\
(\%)\end{array}$ \\
\hline Water & $4,820.41$ & 4.47 \\
Shrubs & $41,395.99$ & 38.34 \\
Wetland shrubs & $19,689.02$ & 18.24 \\
Secondary wetland forest & $1,548.23$ & 1.43 \\
Secondary dryland forest & $27,932.87$ & 25.87 \\
Forest plantation & $2,449.73$ & 2.27 \\
Dryland farming with shrubs & 438.08 & 0.41 \\
Plantation & $4,733.31$ & 4.38 \\
Settlement & $2,321.27$ & 2.15 \\
Wetland & $1,300.88$ & 1.20 \\
Open field & 668.76 & 0.62 \\
Mining & 336.64 & 0.31 \\
Rice field & 323.07 & 0.30 \\
\hline
\end{tabular}


Riparian habitats can provide a greater insect abundance throughout the year, so bodies of water with green vegetation can be considered long-term, high-quality patches (Watanabe et al. 2014). Forest habitat is an important source of Hymenoptera, which is the main food component of swiftlet (Lourie and Tompkins 2000; Luke et al. 2014). In addition, forests have a higher temporal species turnover than other habitats, and this may lead to greater Hymenoptera diversity in forest habitats (Tylianakis et al. 2005). The highest insect abundance will occur at the beginning of the rainy season in which many swiftlets forage around the rice fields. (Kishimoto-Yamada and Itioka 2015). Furthermore, open rice fields are likely to provide higher quality habitat if they are covered with greenery and partially flooded during the rainy season.

The dominant insects found in oil palm plantations are Diptera order (29.4\%) and Hymenoptera (27.78\%). Rahman et al. (2016) found the dominant insects in oil palm plantations are the order of Diptera, Hymenoptera and Coleoptera; the three insect orders are also a source of swiftlet feed. Meanwhile, Siregar et al. (2016) found three insect orders in oil palm and rubber plantations, namely Hymenoptera, Diptera, and Lepidoptera, where Hymenoptera is the most common order.

The practice of swiftlet farming has a significant relationship with the location where the swiftlet house is established. The large swiftlet population is one of the determining factors for the success of swiftlet farming. A large number of swiftlet population is due to abundant feed sources in a certain location, which will contribute to the high production of Edible-nest swiftlets produced (Rahman et al. 2016; Sakai et al. 2016).

The insects found at the time of the study consisted of the order Diptera, Hymenoptera, and Coleoptera (Figure 2). Thus, judging from the insect orders found at the time of the study, the food for swiftlet is available in nature.

\section{Production and financial feasibility}

The production of saliva, which is used to build the nest, is directly related to the period of heat, fertility conditions in the environment and the season (Shah and Aziz 2014). Swiftlet takes about two months to build a nest, lay eggs, incubating until the eggs hatching, caring for the swiftlet chicks (by feeding chicks) until the chicks are ready to fly (Nugroho and Budiman 2013; Mursidah et al. 2020).

In fertile areas, the swiftlet breeding period is more (up to 4 times a year) than in less fertile areas (2-3 times a year). This is related to the abundance of swiftlet food in the form of insects, in which the abundance of insects in fertile areas is more than in less fertile areas (Nugroho and Budiman 2013; Budiman 2019).

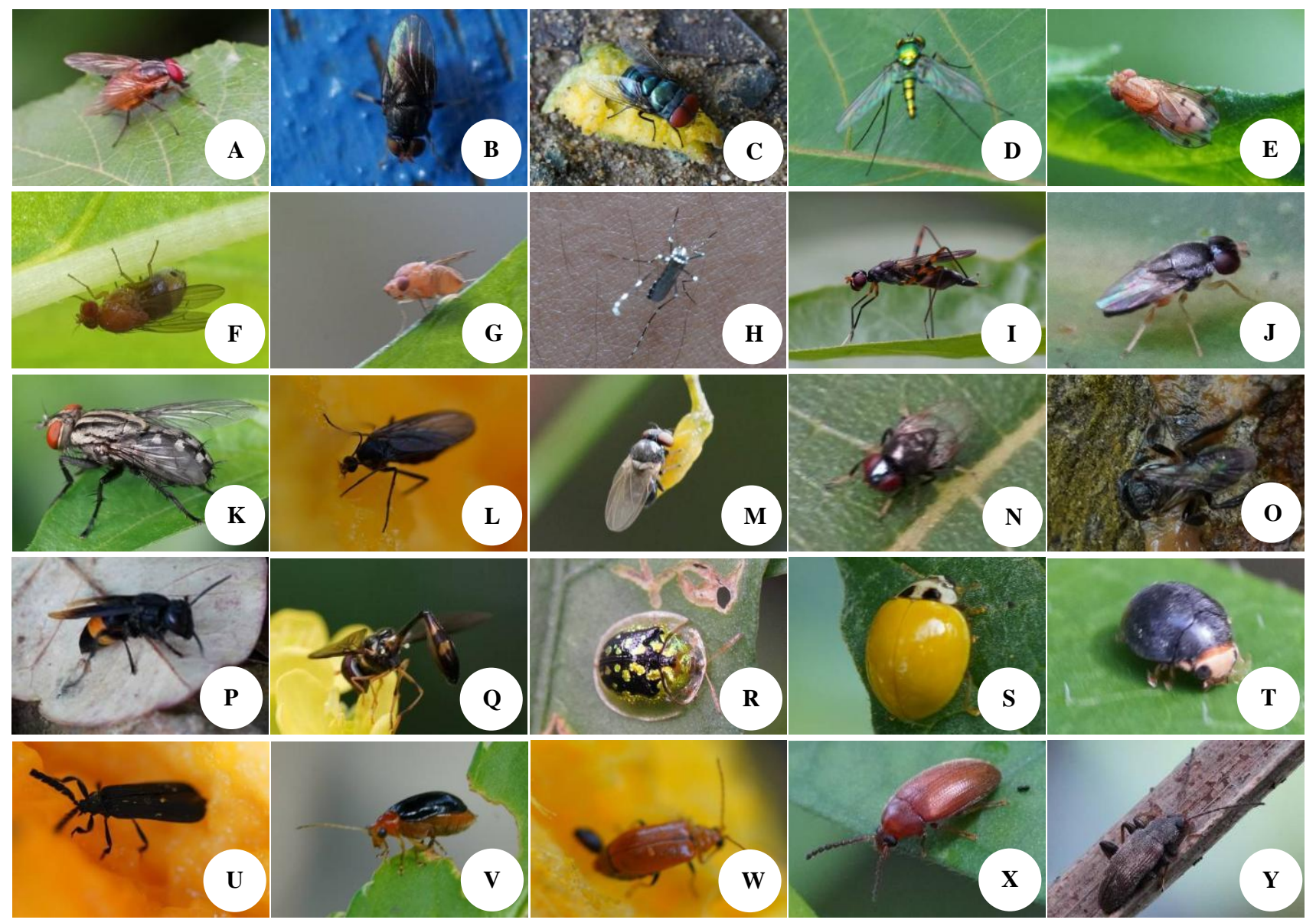

Figure 2. Insects found during the study in Kota Bangun Sub-district, Kutai Kartanegara District, East Kalimantan, Indonesia. A-N. Diptera Order; O-Q. Order Hymenoptera; R-Y. Order of Coleoptera 
Swiftlet mates and builds nests during the rainy season. The number of insects in the rainy season is abundant so that the swiftlet does not need to look for food for long and does not need to travel long distances, and then the swiftlet will look for a mate, mate and prepare for breeding by building a nest (Budiman 2019). The supply of food during the nesting period is of the utmost importance for reproductive success (Dunn et al. 2011). The nesting stage during rainy season will make nesting faster and has a long-term effect on population increase and swiftlet regeneration in future.

Harvesting in the swiftlet house understudy begins in the third year, to make swiftlet feel comfortable and reproduce in the swiftlet house (Nugroho and Budiman 2013; Mursidah et al. 2020). Based on the quality, the types of Edible-nest swiftlets produced include white nests, hatching nests, feather nests, broken nests and crushed nests. Among all types of nests produced, the white nest is the best quality and selling price (Nugroho and Budiman 2013). The production of swiftlet farming at the research location is a hatchery nest in the form of a raw nest (not yet cleaned of swiftlet feathers) (Figure 3). The harvest carried out is the harvest of hatchlings, meaning that the nests will be harvested when the young swiftlet can fly. This way of harvesting was chosen in the hope of increasing the swiftlet population (Nugroho and Budiman 2013; Mursidah et al. 2020).

\section{Model 1: swiftlet house area of $192 \mathrm{~m}^{2}$}

This swiftlet house has a length of $8 \mathrm{~m}$ and a width of $6 \mathrm{~m}$, consisting of 4 floors, assuming an economical life of
17 years. The costs incurred for swiftlet farming include investment costs (buildings and equipment) and operational costs (maintenance, security, harvesting, and management costs). For a swiftlet house with a size of $192 \mathrm{~m}^{2}$, the investment costs are IDR 340.00 million while the operational costs are IDR 623.25 million, so that the total costs incurred for 17 years are IDR 963.25 million, or the average cost incurred is IDR 56.66 million per year.

Edible-nest swiftlets are harvested in the third year, with a total production of $4.50 \mathrm{~kg}$ or $5.859 \mathrm{~g} \mathrm{~m}^{-2}$ period ${ }^{-1}$. Production will continue to increase until reaching the largest production in the 10th year of $22.00 \mathrm{~kg}$ or $28.646 \mathrm{~g}$ $\mathrm{m}^{-2}$ period $^{-1}$. When viewed from the average product (AP) and marginal product (MP), the optimum production will be achieved in the $7^{\text {th }}$ year with a production of $11.75 \mathrm{~kg}$ or $15.299 \mathrm{~g} \mathrm{~m}^{-2}$ period $^{-1}$ (Table 3; Figure 4.A). Based on the number of edible-nest swiftlets production harvested, the swiftlet population in the swiftlet house can be calculated. At the beginning of production in the third year, the swiftlet population in the swiftlet house is 321 birds. When production reaches optimal, the swiftlet population is 839 birds, while the swiftlet population at maximum production is 1,751 birds.

For farming with a long investment period (including swiftlet farming), a feasibility analysis is required. One of the aspects assessed is the financial aspect. Some of the criteria used to assess the financial aspects are Net B/C, NPV, IRR, and PP. For the calculation of financial feasibility, the assumption of a discount factor of $1 \%$ is used.

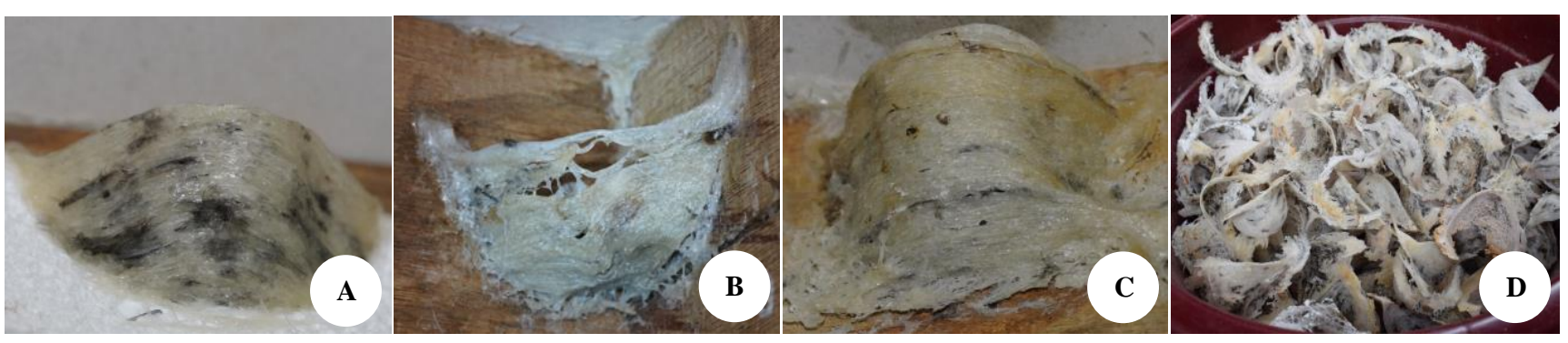

Figure 3. Types of swiftlet nest from Kota Bangun, East Kalimantan, Indonesia. A. Nest bowl; B. Corner nest; C. Bakpao nest; D. Harvested nests

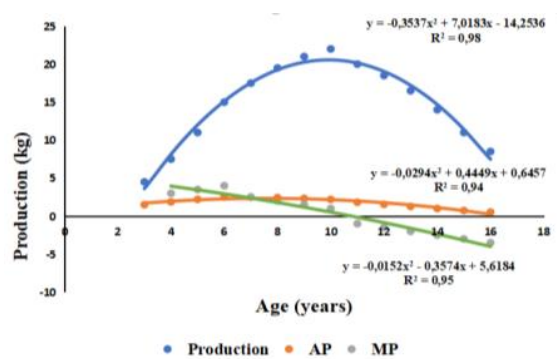

A

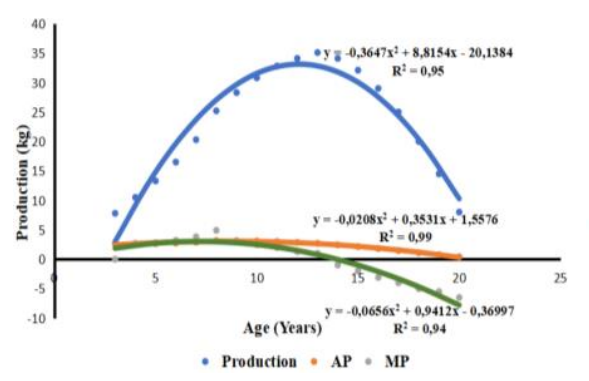

B

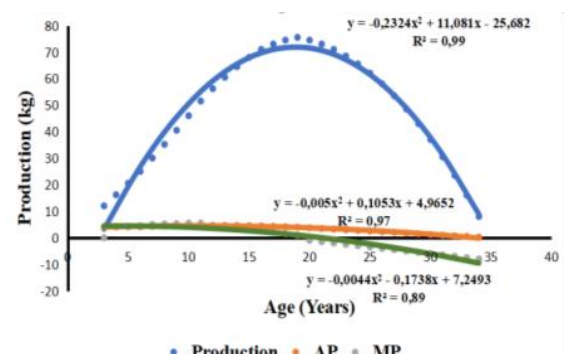

C

Figure 4. The production curve of swiftlet farming. A. Business Model $1\left(192 \mathrm{~m}^{2}\right)$; B. Business Model 2 (256m²); C. Business Model 3 (800m²) 
Table 3. Production Model 1: swiftlets house area is $192 \mathrm{~m}^{2}$

\begin{tabular}{cccc}
\hline Ages & $\mathbf{P}$ & $\mathbf{A P}$ & $\mathbf{M P}$ \\
\hline 1 & 0.00 & 0.00 & 0.00 \\
2 & 0.00 & 0.00 & 0.00 \\
3 & 4.50 & 1.50 & 0.00 \\
4 & 7.50 & 1.88 & 3.00 \\
5 & 11.00 & 2.20 & 3.50 \\
6 & 15.00 & 2.50 & 4.00 \\
7 & 17.50 & 2.50 & 2.50 \\
8 & 19.50 & 2.44 & 2.00 \\
9 & 21.00 & 2.33 & 1.50 \\
\hline
\end{tabular}

\begin{tabular}{cccc}
\hline Ages & P & AP & MP \\
\hline 10 & 22.00 & 2.20 & 1.00 \\
11 & 20.00 & 1.82 & -1.00 \\
12 & 18.50 & 1.54 & -1.50 \\
13 & 16.50 & 1.27 & -2.00 \\
14 & 14.00 & 1.00 & -2.50 \\
15 & 11.00 & 0.73 & -3.00 \\
16 & 8.50 & 0.53 & -3.50 \\
17 & 4.50 & 0.26 & -4.00 \\
\hline
\end{tabular}

Note: Ages (year); P: Production (kg); AP: average production $\left(\mathrm{kg}\right.$ years $\left.^{-1}\right)$; MP: marginal production $(\mathrm{kg})$

Table 4. Production Model 2: swiftlets house area is $256 \mathrm{~m}^{2}$

\begin{tabular}{cccc}
\hline Ages & $\mathbf{P}$ & AP & MP \\
\hline 1 & 0.00 & 0.00 & 0.00 \\
2 & 0.00 & 0.00 & 0.00 \\
3 & 7.80 & 2.60 & 0.00 \\
4 & 10.50 & 2.63 & 2.70 \\
5 & 13.30 & 2.66 & 2.80 \\
6 & 16.50 & 2.75 & 3.20 \\
7 & 20.30 & 2.90 & 3.80 \\
8 & 25.20 & 3.15 & 4.90 \\
9 & 28.30 & 3.14 & 3.10 \\
10 & 30.80 & 3.08 & 2.50 \\
\hline
\end{tabular}

\begin{tabular}{cccc}
\hline Ages & $\mathbf{P}$ & AP & MP \\
\hline 11 & 32.80 & 2.98 & 2.00 \\
12 & 34.10 & 2.84 & 1.30 \\
13 & 35.10 & 2.70 & 1.00 \\
14 & 34.10 & 2.44 & -1.00 \\
15 & 32.10 & 2.14 & -2.00 \\
16 & 29.00 & 1.81 & -3.10 \\
17 & 25.00 & 1.47 & -4.00 \\
18 & 20.00 & 1.11 & -5.00 \\
19 & 14.50 & 0.76 & -5.50 \\
20 & 8.00 & 0.40 & -6.50 \\
\hline
\end{tabular}

Note: Ages (year); P: Production (kg); AP: average production $\left(\mathrm{kg}\right.$ years $\left.{ }^{-1}\right)$; MP: marginal production $(\mathrm{kg})$

Table 5. Production Model 3: swiftlets house area is $800 \mathrm{~m}^{2}$

\begin{tabular}{|c|c|c|c|c|c|c|c|}
\hline Ages & $\mathbf{P}$ & AP & MP & Ages & $\mathbf{P}$ & AP & MP \\
\hline 1 & 0.00 & 0.00 & 0.00 & 18 & 74.50 & 4.14 & 1.50 \\
\hline 2 & 0.00 & 0.00 & 0.00 & 19 & 75.50 & 3.97 & 1.00 \\
\hline 3 & 12.00 & 4.00 & 0.00 & 20 & 74.50 & 3.73 & -1.00 \\
\hline 4 & 16.20 & 4.05 & 4.20 & 21 & 73.00 & 3.48 & -1.50 \\
\hline 5 & 20.50 & 4.10 & 4.30 & 22 & 71.00 & 3.23 & -2.00 \\
\hline 6 & 25.00 & 4.17 & 4.50 & 23 & 68.50 & 2.98 & -2.50 \\
\hline 7 & 30.00 & 4.29 & 5.00 & 24 & 65.50 & 2.73 & -3.00 \\
\hline 8 & 35.20 & 4.40 & 5.20 & 25 & 62.00 & 2.48 & -3.50 \\
\hline 9 & 40.50 & 4.50 & 5.30 & 26 & 58.00 & 2.23 & -4.00 \\
\hline 10 & 46.00 & 4.60 & 5.50 & 27 & 53.50 & 1.98 & -4.50 \\
\hline 11 & 51.50 & 4.68 & 5.50 & 28 & 48.50 & 1.73 & -5.00 \\
\hline 12 & 56.20 & 4.68 & 4.70 & 29 & 43.00 & 1.48 & -5.50 \\
\hline 13 & 60.50 & 4.65 & 4.30 & 30 & 37.00 & 1.23 & -6.00 \\
\hline 14 & 64.50 & 4.61 & 4.00 & 31 & 30.50 & 0.98 & -6.50 \\
\hline 15 & 68.00 & 4.53 & 3.50 & 32 & 23.50 & 0.73 & -7.00 \\
\hline 16 & 71.00 & 4.44 & 3.00 & 33 & 16.00 & 0.48 & -7.50 \\
\hline 17 & 73.00 & 4.29 & 2.00 & 34 & 8.00 & 0.24 & -8.00 \\
\hline
\end{tabular}

Note: Ages (year); P: Production (kg); AP: average production $\left(\mathrm{kg}\right.$ years $\left.{ }^{-1}\right)$; MP: marginal production $(\mathrm{kg})$

Table 6. The financial feasibility assessment of swiftlet farming

\begin{tabular}{cccccc}
\hline Model & $\begin{array}{c}\text { House } \\
\text { area (m2) }\end{array}$ & Net B/C & $\begin{array}{c}\text { NPV } \\
\text { (million } \\
\text { IDR) }\end{array}$ & IRR (\%) & PP (year) \\
\hline 1 & 192 & 1.96 & 293.26 & 22.40 & 6.78 \\
2 & 256 & 2.61 & 577.66 & 23.29 & 4.90 \\
3 & 800 & 2.51 & $1,245.33$ & 25.13 & 8.84 \\
\hline
\end{tabular}

Note: net benefit-cost ratio (Net B/C); net present value (NPV); internal rate of return (IRR); payback period (PP)
For a swiftlet house with an area of $192 \mathrm{~m}^{2}$, the Net B/C is obtained by 1.96 , meaning that if the cost increases by IDR 1, a profit of IDR 1.96 will be obtained (Table 6). Based on the Net $\mathrm{B} / \mathrm{C}$ value that is greater than 1 , it can be said that this business is financially feasible. The next criterion is NPV, which obtains an NPV of IDR 293.26 million (NPV> 0), meaning that swiftlet farming is financially feasible. The efficiency of an investment can be seen from the percentage of IRR (Romele 2013). The IRR of a swiftlet house with an area of $192 \mathrm{~m}^{2}$ is $22.4 \%$. The value of IRR> discount factor shows that the swiftlet farming on Model 1 is considered financially feasible. The time needed to return investment (PP) in Business Model 1 is 6.78 years, and with an investment period of 17 years, this business is feasible because the capital will return before the investment period ends.

\section{Model 2: swiftlet house area of $256 \mathbf{~ m}^{2}$}

This swiftlet house has a length of $8 \mathrm{~m}$ and a width of $8 \mathrm{~m}$, consisting of 4 floors, assumed to have an economic life of 20 years. The investment cost of a swiftlet house with an area of $256 \mathrm{~m}^{2}$ is IDR 382.00 million and an operational cost of IDR1,628.79 million, so that the total costs incurred for 20 years is IDR 2,010.79 million, or the average cost incurred is IDR 100.54 million per year.

Edible-nest swiftlets began to be harvested in the third year, with an initial production of $7.80 \mathrm{~kg}$ or $7.617 \mathrm{~g} \mathrm{~m}^{-2}$ period $^{-1}$. Every year, edible-nest swiftlets production increases, reaching the highest production in the $13^{\text {th }}$ year, respectively as much as $35.1 \mathrm{~kg}$ or $34.277 \mathrm{~g} \mathrm{~m}^{-2}$ period ${ }^{-1}$. When viewed from the average product (AP) and marginal product (MP), the optimum production will be achieved in the $10^{\text {th }}$ year, amounting to $30.80 \mathrm{~kg}$ or $30.078 \mathrm{~g} \mathrm{~m}^{-2}$ period ${ }^{1}$ (Table 4; Figure 4.B). The population of swiftlet in the swiftlet house, measuring $256 \mathrm{~m}^{2}$ at the beginning of production in the third year, is 557 birds. When production reaches optimal, the swiftlet population is 2,200 birds, while the swiftlet population at maximum production is 2,507 birds.

In a swiftlet house with an area of $256 \mathrm{~m}^{2}$, the net value of $\mathrm{B} / \mathrm{C}>1$ is 2.61 (meaning that a profit of IDR 2.61 will be obtained from every IDR spent) (Table 6). Meanwhile, the NPV value obtained is IDR577.66 million, indicating that swiftlet farming is feasible because the NPV value is greater than zero. The IRR figure of $23.29 \%$ indicates that this business is feasible because the IRR is higher than $1 \%$ (discount factor). The PP for Business Model 2 is 4.90 years because the capital will be returned before the investment period ends (20 years); therefore, this business is feasible.

\section{Model 3: swiftlet house area of $800 \mathbf{~ m}^{2}$}

This swiftlet house has a length of $20 \mathrm{~m}$ and a width of $8 \mathrm{~m}$, consisting of 5 floors, assuming an economical life of 34 years. For a swiftlet house with a size of $800 \mathrm{~m} 2$, the investment costs incurred are IDR 920 million and the operational costs are IDR 5,101.25 million, so that the total costs incurred for 34 years are IDR 6,021.25 million or the average cost incurred is IDR 177.10 million per year. 
Edible-nest swiftlets are harvested in the third year, with a total production of $12.00 \mathrm{~kg}$ or $3.750 \mathrm{~g} \mathrm{~m}^{-2}$ period $^{-1}$. Production will continue to increase until reaching the largest production in the $19^{\text {th }}$ year of $75.50 \mathrm{~kg}$ or $23.594 \mathrm{~g}$ $\mathrm{m}^{-2}$ period $^{-1}$. When viewed from the average product (AP) and marginal product (MP), the optimum production will be achieved in the $12^{\text {th }}$ year, that is $56.20 \mathrm{~kg}$ or $17.563 \mathrm{~g} \mathrm{~m}^{-}$ ${ }^{2}$ period $^{-1}$ (Table 5; Figure 4.C). The swiftlet in the swiftlet house of $800 \mathrm{~m}^{2}$ at the beginning of production in the third year are 857 birds. When production reaches optimal, the swiftlet population is 4.014 birds, while the swiftlet population at maximum production is 5.394 birds.

In this business model, the net $\mathrm{B} / \mathrm{C}$ is 2.51 , meaning that every IDR 1 spent will provide a benefit of IDR 2.51 (Table 6). This means the project is viable because the net $\mathrm{B} / \mathrm{C}$ value is greater than 1 . The NPV of IDR $1,245.33$ million indicates that this swiftlet farming is viable because the NPV value is greater than zero. The IRR figure of $25.13 \%$ indicates that this business is feasible because the IRR is higher than $1 \%$ (discount factor). The PP for Business Model 3 is 8.84 years because the capital will be returned before the investment period ends (34 years); therefore, this business is feasible.

Based on the financial feasibility analysis of the three business models above, all three business scales are financially feasible. The swiftlet house area of $256 \mathrm{~m}^{2}$ provides higher Net $\mathrm{B} / \mathrm{C}$ values compared to the swiftlet house areas of $192 \mathrm{~m}^{2}$ and $800 \mathrm{~m}^{2}$, but the swiftlet house area of $800 \mathrm{~m}^{2}$ provides higher IRR values compared to the swiftlet house areas of $192 \mathrm{~m}^{2}$ and $256 \mathrm{~m}^{2}$ Business scale with an area of $512 \mathrm{~m}^{2}$ (Mursidah et al. 2020) and $216 \mathrm{~m}^{2}$ (Sumardi et al. 2018) can provide better performance. Business scale of $512 \mathrm{~m}^{2}$ with a value of 4.06 for Net B/C, IDR 1,403.79 million for NPV, 3\% for IRR and PP 5.44 years (with a production period of 27 years), while the business scale of $216 \mathrm{~m}^{2}$ with a value of Net B/C of 2.19 , NPV IDR 334.41 million, IRR 35.18\%, and PP 4.33 years (with a production period of 5 years). However, when compared with the financial feasibility of a swiftlet house with an area of $1,600 \mathrm{~m}^{2}$ (with a value of 2.27 for Net $\mathrm{B} / \mathrm{C}$, IDR $1,774.83$ million for NPV, $24.09 \%$ for IRR and 9.4 years for PP), the third scale of the business understudy can provide better financial feasibility.

Swiftlet farming is a high-risk business. However, with the level of income (as measured by financial viability), most swiftlet farmers take the risk. Business risks from swiftlet farming (Alias et al. 2013) include the possibility of theft and attack by pests. To maintain the sustainability of their business, a swiftlet farmer needs to be more intensive in managing his business, including by improving physical facilities, financial management skills, and social networking (Kamaruddin et al. 2019; Rahman et al. 2019). The results of the study suggest that land cover greatly determines the availability of feed for swiftlet in the form of flying insects. Thus, one important factor that must be considered when determining the location of swiftlet farming is the condition of land cover around the swiftlet house. This is because the swiftlet will look for a place where there is an abundant source of feed. In addition, the fulfillment of swiftlet feed needs in the farming swiftlet at the research location depends entirely on the availability of flying insects in nature. We found that of the three swiftlet houses studied, all of them are economically profitable and financially feasible. The swiftlet house with a size of 800 $\mathrm{m}^{2}$ has the highest financial feasibility, although the value of the financial feasibility is still smaller than the $512 \mathrm{~m}^{2}$ swiftlet house (Mursidah et al. 2020). Therefore, it can be said that the swiftlet house with a size of $512 \mathrm{~m}^{2}$ provides the best financial performance. Population growth, land-use change, and government policies will result in changes in land cover (Berihun et al. 2019). The density of swiftlet houses or large population in same area can affect its production. The foraging competition can cause lower production. One of the policies is to turn Sebelimbingan Village into a Swiftlet Village (Kampung Walet) as a conservation effort, requiring an understanding of the associations of behavior, physiology, and environmental conditions that swiftlet likes (Mane and Manchi 2017). Changes in land cover will affect the availability of food for swiftlet. Swiftlet feed, which previously depends entirely on its availability in nature, will be supported by artificial feeding. The provision of artificial feed will certainly have an effect on the costs incurred. The addition of the cost of artificial feed will certainly increase the total costs of swiftlet farming, which in turn will affect the assessment of the financial feasibility of the business. In addition, most swiftlet farmers learn how to handle swiftlet by learning from successful swiftlet farmers.

\section{ACKNOWLEDGEMENTS}

The authors would like to thank the respondent for their information during the research in the field, Abdul Sahid and Nanang Angien, for sharing about insects and swiftlet. Cartography and GIS Laboratory Assistant, Faculty of Agriculture, Mulawarman University, for their assistance in making maps. Muhammad Siddik and Aditia Nugraha, respectively, for their contribution in making documentation, as well as all parties who have helped the smooth running of the research. Special thanks to Rosli Ramli and anonymous reviewers for their constructive feedback to improve the manuscript.

\section{REFERENCES}

Ahmad H, Ong SQ, Tan EH. 2019. The diet for edible-nest swiftlets: nutritional composition and cost of life stages of Megaselia scalaris Loew (Diptera: Phoridae) bred on 3 commercial breeding materials. Intl J Insect Sci 1 1(2019): 1-5. DOI: 10.1177/1179543318823533.

Alias A, Poh AY, Ma NZ, Din MAM. 2013. Investment in swiftlet hotels in Malaysia-does ROI compensate investment risks?. Afr J Bus Manag 7(38): 3936-3943. DOI: 10.5897/AJBM11.032.

Arshad A. 2012. Net present value is better than the internal rate of return. Interdisciplin J Contempro Bus 4(8): 211-219.

Asciuto A, Schimmenti E, Cottone C, Borsellino V. 2019. A financial feasibility study on aquaponics system in a Mediterranean urban context. Urban For Urban Gree 38(2019): 397-402. DOI: 10.1016/j.ufug.2019.02.001

Ashari. 2020. Exports of swallow's nests are still resilient during the pandemic. Center for Socio-Economic and Agricultural Policy. Ministry of Agriculture. http://pse.litbang.pertanian.go.id/ind/index.php/covid-19/berita- 
covid19/541-ekspor-sarang-burung-walet-masih-tangguh-pada-masapandemi. [Indonesian]

Babji AS, Nurfatin MH, Etty SIK, Masitah M. 2015. Secrets of ediblenest swiftlets. UTAR Agric Sci J 1(1): 32-37.

Babji AS, Daud NA. 2019. Physicochemical properties of glycan within swiftlet's nest (Aerodramus fuciphagus) as potential prebiotic. ACTA Sci Med Sci 3 (9): 9-13.

Banerjee S. 2015. Contravention between NPV and IRR due to timing of cash flows: a case of capital budgeting decision of an oil refinery company. Am J Theoretical Appl Bus 1(2): 48-52. DOI: 10.11648/j.ajtab.20150102.13.

Begon M, Townsend CR, Harper JL. 2006. Ecology: from individuals to ecosystems, 4th eds. Blackwell, Oxford, UK.

Berihun ML,Tsunekawa A, Haregeweyn N, Meshesha DT, Adgo E, Tsubo M, Masunaga T, Fenta AA, Sultan D, Yibeltal M. 2019. Exploring land use/land cover changes, drivers and their implications in contrasting agro-ecological environments of Ethiopia. Land Use Policy 87: 104052. DOI: 10.1016/j.landusepol.2019.104052.

Budiman A. 2019. 101 tips for overcoming swiftlet farming problems. Agromedia Pustaka, Jakarta. [Indonesian]

Cadigal GM. 2015. Collection and trade dynamics of edible nest swiftlet (Aerodramus fuciphagus Thunberg, 1812) nest in northern Palawan, Philippines. Our Palawan 1: 23-34.

Careena S, Sani D, Tan SN, Lim CW, Hassan S, Norhafizah M, Kirby BP, Ideris A, Stanislas J, Basri HB, Lim CTS. 2018. Effect of edible bird's nest extract on lipopolysaccharide-induced impairment of learning and memory in Wistar rats. Hindawi evidence-based complementary and alternative medicine 2018: 9318789. DOI: $10.1155 / 2018 / 9318789$

Chan GKL, Wong ZCF, Lam KYC, Cheng LKW, Zhang LM, Lin H, Dong TT, Tsim KWK. 2015. Edible bird's nest, an Asian health food supplement, possesses skin lightening activities: identification of $\mathrm{N}$ acetylneuraminic acid as active ingredient. J Cosmet Dermatol Sci Appl (5): 262-274.

Chua LS and Zukefli SN. 2016. A comprehensive review of edible-nest swiftlets and swiftlet farming. J Integr Med 14(6): 415-428. DOI: 10.1016/S2095-4964(16)60282-0.

Chye SM, Tai SK, Koh RY, Ng KY. 2017. A mini-review on medicinal effects of edible bird's nest. Lett Health Biol Sci 2(1): 65-67. DOI 10.15436/2475-6245.17.016.

Connolly C. 2016. 'A place for everything': moral landscape of 'swiftlet farming' in George Town, Malaysia. Geoforum 77(2016): 181-191. DOI: 10.1016/j.geoforum.2016.11.005.

Daud NA, Sarbini SR, Babji AS, Yusop SM, Lim SJ. 2019 Characterization of edible swiftlet"s nest as a prebiotic ingredient using a simulated colon model. Ann Microbiol 69(14): 1235-1246.

Delgado TS, McCall MK, Binqüist CL. 2016. Recognized but not supported: assessing the incorporation of non-timber forest products into Mexican forest policy. For Pol Econ 71: 36-42. DOI: 10.1016/j.forpol.2016.07.002.

Duguma LA. 2013. Financial analysis of agroforestry land uses and its implication for smallholder farmer livelihood improvement in Ethiopia. Agrofor Syst 87: 217-231. DOI: 10.1007/s10457-012-9537-

Dunn PO, Winkler DW, Whittingham LA, Hannon AJ, Robertson RJ 2011. A test of the mismatch hypothesis: how is timing of reproduction related to food abundance in an aerial insectivore? Ecology 92 (2): 450-461.

Fischer JH, Kaaden AVD. 2016. Glossy swiftlet Collocalia esculenta exhibiting signs of the pigment deficiency 'dilution'. BirdingASIA 25: 84-86.

Fujita M and Leh C. 2020. The feeding ecology of edible-nest swiftlets in a modified landscape in Sarawak. In: Ishikawa N, Soda R (eds) Anthropogenic Tropical Forests, Advances in Asian HumanEnvironmental Research. Springer Nature, Singapore.

Harbi J, Erbaugh JT, Sadiq M, Haasler B, Nur Rochmat DR. 2018 Making a bridge between livelihoods and forest conservation: lessons from non-timber forest products' utilization in South Sumatra, Indonesia. For Policy Econ 94: 1-10. DOI 10.1016/j.forpol.2018.05.011.

Hoang LH, Binh DT, Thu NTA. 2014. Population genetics white-nest swiftlet Aerodramus fuciphagus. Subspecies in Vietnam. J Agric Rural Dev 2014: 77-82.

Hoang LH, Binh DT, Thu NTA, Binh CH. 2015. Population genetics white-nest swiftlet Aerodramus fuciphagus in Vietnam. J Fisheries Sci Technol. Special issue-2015: 57-62.
Hopkinson M. 2016. The case for project net present value (NPV) and NPV risk models. PM World J 5 (6): 2-9.

Hou Z, Imam MU, Ismail M, Azmi NH, Ismail N, Ideris A, Mahmud R. 2015. Lactoferrin and ovotransferrin contribute toward antioxidative effects of edible bird's nest against hydrogen peroxide-induced oxidative stress in human SH-SY5Y cells. Biosci Biotechnol Biochem. DOI: 10.1080/09168451.2015.1050989

Hou Z, Iman MU, Ismail M, Ooi DJ, Ideris A, Mahmud R, 2015. Nutrigenomic effects of edible bird's nest on insulin signalling in ovariectomized rats. Drug Des. Dev Ther 9: 4115-4125. DOI: 10.2147/DDDT.S80743.

Ibrahim SH, Baharun A, Kabiru A. 2011. Study on suitable construction materials for swiftlet farming using energy plus; Full-Paper of International Conference and Training on Swiftlet Ranching (ICOTOS 2011). University Malaysia Serawak (Unimas), Malaysia, 17-19 July 2011.

Idris A, Abdullah AA, Rehman MA. 2014. An overview of the study of the right habitat and suitable environment factors that influence the success of edible bird nest production in Malaysia. Asian J Agric Res 8 (1): 1-16. DOI: 10.3923/ajar.2014.1.16.

Jamaluddin NR, Tukiran NA., Fadzillah NA, Fathi S. 2019. Overview of edible bird's nest and their contemporary issues. Food Control 104: 247-255. DOI: 10.1016/j.foodcont.2019.04.042.

Kamaruddin R, Engku Ismail CEM, Ahmad SA. 2019. Key factors for the sustainable production of swiftlet birds nest industry in Malaysia: a case study in Nothern Peninsular Malaysia. Intl J Sup Chain Mgt 8 33(1): 724-733

Ke S, Yan R, Qiao D, Zhu L. 2018. Cost-benefit analysis of an agroforestry innovation karst land: replacing sweet potato by sealwort (Polygonatum cyrtonema) under plum trees in Chunfeng Village, Sichuan Province, China. For Trees Livelihoods 27: 217-229. DOI: 10.1080/14728028.2018.1515040.

Kishimoto-Yamada K \& Itioka T. 2015. How much have we learned about seasonality in tropical insect abundance since Wolda (1988)? Entomol Sci18(4): 407-419. DOI: 10.1111/ens.12134.

Looi QH, Omar AR. 2016. Swiftlets and edible bird's nest industry in Asia. Pertanika J Sch Res Rev 2(1): 32-48.

Lourie SA, Tompkins DM. 2000. The diets of Malaysian swiftlets. Intl J Avian Sci 142 (4): 596-602. DOI: 10.1111/j. 1474919X.2000.tb04459.x.

Luke SH, Fayle TM, Eggleton P, Turner EC, Davies RG. 2014. Functional structure of ant and termite assemblages in old-growth forest, logged forest and oil palm plantation in Malaysian Borneo. Biodivers Conserv 23: 2817-2832. DOI: 10.1007/s10531-014-0750-2.

Ma F, Liu D. 2012. Sketch of the edible bird's nest and its important bioactivities. Food Rest Intl 48: 559-567. DOI: 10.1016/j.foodres.2012.06.001.

Manchi S and Sankaran R. 2014. Protection of the white-nest swiftlet Aerodramus fuciphagus in the Andaman Islands, India: an assessment. Oryx. DOI: 10.1017/S0030605311000603.

Mane AM and Manchi SS. 2017. Roosting patterns of the edible-nest swiftlet (Aerodramus fuciphagus) of the Andaman Islands: effects of lunar phase and breeding chronology. Emu-Austral Ornithology. DOI: $10.1080 / 01584197.2017 .1336065$

Mursidah, Lahjie AM, Masjaya, Rayadin Y, Ruslim Y. 2020. The ecology, productivity and economy of swiftlet (Aerodramus fuciphagus) farming in Kota Bangun, East Kalimantan, Indonesia. Biodiversitas 21(7): 3117-3126. DOI: 10.13057/biodiv/d210732 [Indonesian]

Nigussie Z, Tsunekawa A, Haregeweyn N, Adgo E, Tsubo M, Ayalew Z, Abele S. 2020. Economic and financial sustainability of an Acacia decurrens-based Taungya system for farmers in the Upper Blue Nile Basin, Ethiopia. Land Use Pol 90: 104331. DOI: 10.1016/j.landusepol.2019.104331

Nituda CJP, Nuneza OM. 2016. Diet composition of two species of swiftlets from caves of Northern Mindanao, Philippines. Bull Environ Pharmacol Life 5 (5): 48-52.

Nor ASM, Khamis NHH, Yahya A, Khalil K. 2016. Potential and sustainability of swiftlet industries in Malaysia. Intl J Sci Technol 1 (1):1-7.

Nugroho HK, Budiman A. 2013. Complete Guide Swiftlet. Penebar Swadaya. Jakarta. [Indonesian]

Petkliang N, Gale GA, Brunton DH, Bumrungsri S. 2017. Wetland, forest and open paddy land area the key for foraging habitats for Germain's swiftlet (Aerodramus inexpectatus germani) in Southern Thailand. Trop Conserv Sci 10: 1-12. DOI: 10.1177/1940082917698467 
Rahman MA, Ghazali PL, Lian CJ. 2018. Environmental parameters in successful Edible-nest swiftlets houses in Trengganu. J Sustain Sci Manag 13(1): 127-131.

Rahman MA, Ghazali PL, Lian CJ, Basari N, Mamat M, Foziah H, Afthanorhan A. 2019. Suitable ranching practices in successful edible bird nest swiftlet houses in Trengganu. Intl J Recent Technol Eng 7(5S4): 600-604

Rahman SFSA, Nor HM, Burhanuddin M. 2016. Diversity of the insect in the diet of edible nest swiftlets in oil palm plantations. J Bio Env Sci 8(4): 39-48.

Ramji MFS, Rahman MA. 2013. Roosting and nest-building behaviour of the white-nest swiftlet Aerodramus fuciphagus (Thunberg) (Aves: Apodidae) in farmed colonies. Raffles Bull Zool 29: 225-235.

Razali R, Yaakop S, Abdullah M, Ghazali SZ, Zuki AA. 2015. Insect species composition in an under SRI management in Tanjung Karang, Selangor, Malaysia. Malays Appl Biol 44(4): 73-80.

Rist L, Shanley P, Sunderland T, Sheil D, Ndoye O, Liswanti N, Tieguhong J. 2012. The impacts of selective logging on non-timber forest products of livelihood importance. For Ecol Manag 268: 57-69. DOI: 10.1016/j.foreco.2011.04.037

Romele L. 2013. Estimation of internal rate of return (IRR) to investments in education in Latvia. Intl J Soc Sci Humanity 3(1): 1-4. DOI 10.7763/IJSSH.2013.V3.180.

Rosyidi S. 2020. Introduction to economic theory: approaches to micro and macroeconomic theory. Rajawali Pers, Jakarta. [Indonesian]

Saengkrajang W, Matan N, Matan N. 2013. Nutritional composition of the farmed edible bird's nest (Collocalia fuchipaga) in Thailand. J Food Compos Anal 31(1): 41-45. DOI: 10.1016/j.jfca.2013.05.001.

Sakai S, Choy YK, Yamada KK, Takano KT, Ichikawa M, Samejima H, Kato Y, Soda R, Ushio M, Saizen I, Nakashizuka T, Itioka T. 2016. Social and ecological factors associated with the use of non-timber forest products by people in rural Borneo. Biol Conserv 204: 340-349. DOI: 10.1016/j.biocon.2016.10.022.

Sanchez-Clavijo LM, Hearns J, Quintana-Ascencio PF. 2016. Modelling the effect of habitat selection mechanisms on population responses to landscape structure. Ecol Model 328: 99-107. DOI: 10.1016/j.ecolmodel.2016.03.004.

Sarmah R. 2012. Non-timber forest products: extraction and impact on plant community structure in and around Namdapha National Park of Arunachal Pradesh, India. Indian J. Plant Sci 1 (3): 192-207.

Shah SW, Aziz NA. 2014. Morphology of the lingual apparatus of the swiftlet, Aerodramus fuciphagus (Aves, Apodiformes, Apodidae). J Microsc Ultrastruct 2: 100-103. DOI: 10.1016/j.jmau.2014.02.006.
Shukri NHM, Nawi NM, Abdullah AM, Mann. 2018. Consumers perception on the quality of controversial contents in edible bird's nest products. Pertanika J Sch Res Rev 4 (1): 1-9.

Siregar EH, Atmowidi T, Kahono S. 2016. Diversity and abundance of insect pollinators in different agricultural lands in Jambi, Sumatra. Hayati 23(1): 13-17. DOI: 10.1016/j.hjb.2015.11.002. [Indonesian]

Sisak L, Riedl M, Dudik R. 2016. Non-market non-timber forest products in the Czech Republic - their socio-economic effects and trends in forest land use. Land Use Pol 50: 390-398. DOI: 10.1016/j.landusepol.2015.10.006

Sososutiksno C, Gasperz J. 2017. Economic and financial feasibility of Abalone culture development in Hulaliu Village, District of Maluku Tengah, Maluku Province. AACL Bioflux 10 (6): 1492-1498.

Sugiyono. 2016. Research Method, Quantitave, Qualitative and R\&D. Alfabeta, Bandung. [Indonesian]

Sumardi D, Pordamantra, Sunariyo. 2018. Evaluation of the business feasibility of swallow nest in the Telaga Antang Sub-district East Kotawaringin District (Case study: Suwaji's edible-nest swiftlets business). J Socio Econ Agric 13 (2): 51-58. [Indonesian]

Thorburn C. 2015. The edible nest swiftlet industry in South Asia: capitalism meets commensalism. Hum Ecol 43 (1): 179-184. DOI: 10.1007/s10745-014-9713-1.

Tylianakis JM, Klein A, Tscharntke T. 2005. Spatiotemporal variation in the diversity of Hymenoptera across a tropical habitat gradient. Ecology 86(12):3296-3302. DOI: 10.1890/05-0371.

Vimala B, Hussain H, Wan Nazaimoon WM. 2012. Effects of edible bird's nest on tumour necrosis factor-alpha secretion, nitric oxide production and cell viability of lipopolysaccharide-stimulated RAW 264.7 macrophages. Food Agric Immunol 23: 303-314. DOI: 10.1080/09540105.2011.625494.

Watanabe YY, Ito M, Takahashi A. 2014 Testing optimal foraging theory in a penguin-krill system. Proc. R. Soc. B 281: 20132376. DOI: 10.1098/rspb.2013.2376.

Wong RS. 2013. Edible bird's nest: food or medicine?. Chin J Integr Med 19: 642-649. DOI: 10.1007/s11655-013-1563-y.

Zhang S, Lai X, Liu X, Li Y, Li B, Huang X, Zhang Q, Chen W, Lin L, Yang G. 2012. Competitive enzyme-linked immunoassay for sialoglycoprotein of edible bird's nest in food and cosmetic. J Agr Food Chem 60: 3580-3585. DOI: 10.1021/jf300865a.

Zulkifli DA, Mansor R, Ajat MMM, Abas F, Ideris A, Abu J. 2019. Differentiation of Malaysian farming and commercialized edible bird's nests through nutritional composition analysis. Pertanika J Trop Agric Sci 42(3): 871-881. 